\title{
Acute severe ulcerative colitis: management advice for internal medicine and emergency physicians
}

\author{
Konstantina Rosiou ${ }^{1} \cdot$ Christian Philipp Selinger ${ }^{1,2}$ (i)
}

Received: 7 December 2020 / Accepted: 8 March 2021 / Published online: 22 March 2021

(c) The Author(s) 2021

\begin{abstract}
Acute severe ulcerative colitis is a medical emergency that warrants in-patient management. This is best served within a multidisciplinary team setting in specialised centres or with expert consultation. Intravenous corticosteroids remain the cornerstone in the management of ASUC and should be initiated promptly, along with general management measures and close monitoring of patients. Unfortunately, one-third of patients will fail to respond to steroids. Response to intravenous corticosteroid therapy needs to be assessed on the third day and rescue therapies, including cyclosporine and infliximab, should be offered to patients not responding. Choice of rescue therapy depends on experience, drug availability and factors associated with each individual patient, such as comorbidities, previous medications or contra-indications to therapy. Patients who have not responded within 7 days to rescue therapy must be considered for surgery. Surgery is a treatment option in ASUC and should not be delayed in cases of failure of medical therapy, because such delays increase surgical morbidity and mortality. This review summarises the current management of acute severe ulcerative colitis and discusses potential future developments.
\end{abstract}

Keywords Ulcerative colitis · Inflammatory bowel disease

\section{Introduction}

Ulcerative colitis (UC) is a chronic inflammatory condition that affects the mucosal surface of the colon, starting from the rectum and extending more proximally in a continuous fashion [1]. Its incidence is rising worldwide [2] and its precise aetiology is unknown and believed to be multifactorial, involving genetic predisposition, epithelial barrier defects, dysregulated immune responses to luminal pathogens as well as environmental factors [3]. Ulcerative colitis is characterised by a relapsing and remitting course [3] and although the majority of patients tend to have a mild to moderate disease course, approximately $15-25 \%$ of patients with UC will experience at least one episode of severe flare of their disease and 10-20\% will present with acute severe ulcerative colitis (ASUC) at diagnosis [4, 5]. Despite improvements

Christian Philipp Selinger

Christian.selinger@web.de

1 Leeds Gastroenterology Institute, Leeds Teaching Hospitals NHS Trust, St James University Hospital, Bexley Wing, Leeds LS9 7TF, UK

2 University of Leeds, Leeds, UK in management, ASUC should still be considered a medical emergency. ASUC is associated with a $20 \%$ risk for colectomy on first admission and this risk rises to $40 \%$ after two admissions [4]. The risk of colectomy in ASUC has also been related to the biological severity at admission based on the fulfilment of the Truelove and Witts criteria, the extent of the disease either at diagnosis or follow-up, male gender and the presence of extra-intestinal manifestations of inflammatory bowel disease (IBD) [4]. Moreover, there remains a $1 \%$ mortality associated with severe flares of UC $[6,7]$. Medical management of ASUC remains a significant challenge for clinicians. The aim of this review is to underline the key principles in the diagnosis and management of ASUC, highlighting at the same time useful advice for internal medicine and emergency physicians involved in the management of patients with ASUC.

\section{Definition}

The diagnosis of acute severe ulcerative colitis is based on the Truelove and Witts criteria as described at their original article in 1955 [8]. Every patient known to have UC 
presenting with bloody diarrhoea $\geq 6$ /day and any sign of systemic toxicity, i.e. at least one of: pulse $>90 / \mathrm{min}$, temperature $>37.8^{\circ} \mathrm{C}$, haemoglobin $<105 \mathrm{~g} / \mathrm{L}$, erythrocyte sedimentation rate $(E S R)>30 \mathrm{~mm} / \mathrm{h}$ should be admitted to hospital for assessment and intensive treatment [9, 10]. C-reactive protein (CRP) is measured more often than ESR and does not show a non-specific increase with age [11] and for this reason, a CRP of $>30 \mathrm{mg} / \mathrm{L}$ has been incorporated in the modified Truelove and Witts criteria endorsed by both the European Crohn's and Colitis Organisation (ECCO) and the British Society of Gastroenterology (BSG) [9, 10]. (Table 1).

\section{Initial assessment}

All patients admitted with ASUC should have initial investigations aiming to assess disease severity, exclude infections and relative contra-indications of rescue therapy and predict outcomes [12]. Baseline investigations are presented in Table 2 and include: full blood count (FBC), CRP, urea and electrolytes (U\&E), liver function tests (LFT's), magnesium, stool cultures and Clostridium difficile ( $C$. difficile) assay, radiological imaging (abdominal X-ray or computed tomography/CT) and flexible sigmoidoscopy.

Stool cultures and microscopy should be performed as early as possible upon admission to exclude infectious diarrhoea and test for $C$. difficile toxin. $C$. difficile infection is associated with increased morbidity and mortality in UC patients, as well as increased risk for surgery and healthcare related costs [13-15]. At the moment, there is no current recommendation as to whether one sample or serial testing for $C$. difficile should be performed and there are studies supporting both sides [16, 17]; however, if $C$. difficile is

Table 1 ASUC definition [8, 10]

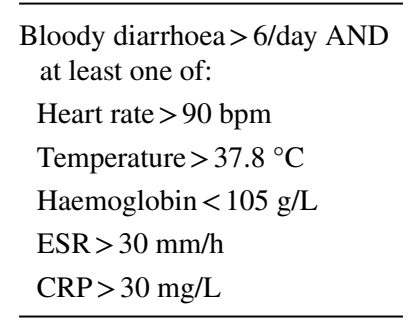

detected, oral vancomycin $500 \mathrm{mg} / 6 \mathrm{~h}$ for 10 days should be given [10].

Radiological imaging plays an important role in the management of patients with ASUC. Plain abdominal X-ray should be requested on admission and serial $\mathrm{X}$-rays are used to monitor disease progression or complications. Toxic megacolon, defined by a colonic diameter of $>5.5 \mathrm{~cm}$ in the presence of systemic toxicity, represents a life-threatening complication of ASUC and in the majority of cases requires immediate surgery. A plain abdominal X-ray can also provide an estimate of the extent of the disease, as the proximal extent of disease correlates with the distal distribution of faecal residue. Moreover, there are predictors of poor prognosis, such as a small bowel dilation $>3 \mathrm{~cm}$, the presence of $\geq 3$ gas-filled loops of small bowel or the visualization of small circular opacities, which represent residual isolated mucosa surrounding an ulceration, that can be assessed with an abdominal radiograph [18]. Routine CT scans have minor impact on the decision to perform colectomy and are not recommended [19]. CT plays a vital role in the detection of complications, especially perforation, while MagneticResonance Imaging (MRI) and ultrasound may be utilised to determine the extent of disease [10].

Early unprepped flexible sigmoidoscopy can aid to confirm diagnosis, assess disease severity and obtain histology, including ruling out Cytomegalovirus (CMV) infection [9, 10]. A complete colonoscopy is not advised as it carries an increased risk of perforation in patients with ASUC and does not offer more clinical information compared to a sigmoidoscopy [9].

CMV infection can be diagnosed by the presence of CMV inclusion bodies on haematoxylin and eosin (H\&E) biopsy staining, by immunohistochemistry and/or tissue Polymerase chain reaction (PCR) [10]. The prevalence of CMV infection during ASUC ranges among different studies; however, it can be over 30\% among steroid-refractory patients [20]. Empirical antiviral therapy should be initiated in patients with moderate-to-severe colitis and a high suspicion of CMV infection (steroid-resistant, severe immunosuppression, etc.) [21]. Those with proven colonic CMV reactivation require antiviral therapy in all cases [21]. Current guidelines recommend treatment with intravenous ganciclovir $5 \mathrm{mg} / \mathrm{kg}$ twice daily for 3-5 days, which should be then switched to oral valganciclovir $900 \mathrm{mg}$ twice daily for 2-3 weeks. In

Table 2 Baseline investigations

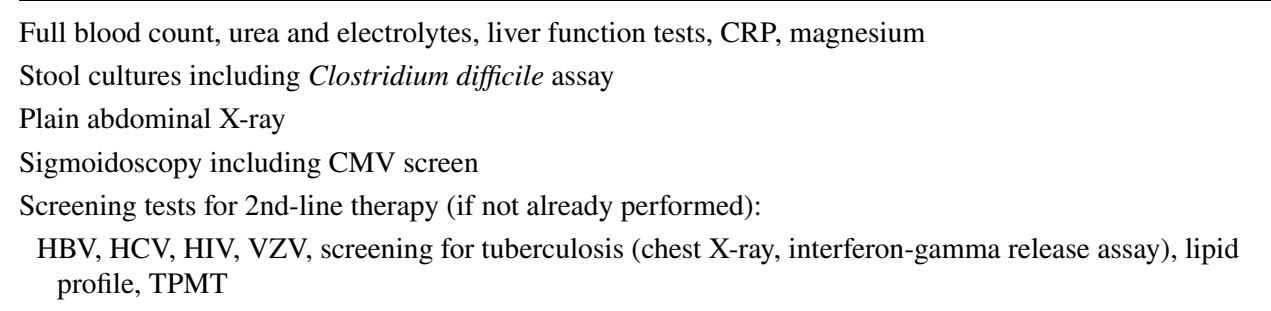


case of systemic CMV reactivation causing either meningoencephalitis, pneumonitis, hepatitis, oesophagitis or colitis, discontinuation of all immunosuppressive medication is advised along with antiviral treatment [22].

Flexible sigmoidoscopy can be utilised to rate the severity of mucosal inflammation. The most commonly used scoring systems are the ulcerative colitis endoscopic index of severity (UCEIS) and the endoscopic Mayo score. The use of endoscopic scoring systems can aid to uniformity at initial assessment as well as follow-up [23, 24]. Moreover, endoscopic scoring systems can be useful in predicting disease outcome. For example, a UCEIS of 7 or 8 is a strong predictor of the need of rescue therapy, colectomy or readmission and this can be useful in early decision-making [25].

Screening tests for second-line therapy are required for all patients unless these tests were already performed as an outpatient prior to presentation with ASUC and include lipid profile, hepatitis $\mathrm{B}$ and $\mathrm{C}$ virus, human immunodeficiency virus (HIV), varicella zoster virus (VZV) (if no history of chicken pox, shingles or varicella vaccination), screening for tuberculosis with clinical risk stratification, chest X-ray and interferon-gamma release assay [10]. Thiopurine methyltransferase (TMPT) should also be measured in view of possible use of thiopurines as maintenance therapy, as it can be useful in predicting patients at risk of developing significant drug toxicity [12].

\section{General management (Table 3)}

Patients admitted with ASUC are best managed in the setting of a multidisciplinary team including a gastroenterologist, colorectal surgeon, gastroenterology nurse, dietician, pharmacist and stomal therapist on a specialised gastrointestinal ward. If such care is unavailable, discussion with a specialist centre to establish the management plan at an early stage should be sought $[9,12]$. Access to emergency surgery is vital for all patients with ASUC to manage potential complications and for those failing 1st- and 2nd-line medical therapies.

Other causes of symptoms should always be considered and excluded, including infective, ischaemic, or druginduced colitis [26]. Patients should be assessed at least once daily including physical examination, assessment of haemodynamic status, stool charts, blood tests and abdominal radiographs when required $[12,26]$. Intravenous fluids and electrolytes should be replaced as required to correct and prevent dehydration and electrolyte imbalance. Hypokalaemia and hypomagnesaemia should be corrected because they can promote toxic dilatation $[9,27]$.

Non-steroidal anti-inflammatory drugs (NSAIDs) have been associated with disease exacerbation and should therefore be avoided [9, 27, 28]. Moreover, anticholinergic, antidiarrhoeal and opioid drugs should be withdrawn because they can precipitate colonic dilatation [9, 27, 29].

The nutritional status of the patient should be assessed preferably by a trained dietician [12] and nutritional support should be instituted for malnourished patients [9]. There is no proven role for routine parenteral nutrition and enteral nutrition is considered more appropriate and associated with less complications $[9,30]$. Total bowel rest does not alter outcomes in patients with ASUC and is therefore not recommended [9, 31].

Patients with IBD have a threefold higher risk of venous thromboembolism (VTE) compared to patients without IBD and this risk increases even more during flares of the disease and hospitalisation with need of steroids [32-35]. For this reason, VTE prophylaxis both pharmacological with subcutaneous low molecular weight heparin and mechanical with graduated compression stockings is advised unless contraindicated $[9,12,36]$. The presence of rectal bleeding is not a contraindication to subcutaneous low molecular weight heparin.

Routine use of antibiotics in ASUC is not recommended. Controlled trials of oral or intravenous metronidazole, tobramycin, or ciprofloxacin in patients with ASUC did not show any additional benefit compared to conventional
Table 3 ASUC checklist

\begin{tabular}{ll}
\hline$\checkmark$ & $\begin{array}{c}\text { Admit all patients with ASUC to a specialised gastrointestinal ward for multidisciplinary } \\
\text { care OR seek specialist input at early stage }\end{array}$ \\
$\checkmark$ & Exclude other causes of symptoms (including infective, ischaemic or drug-induced colitis) \\
$\checkmark$ & $\begin{array}{c}\text { Assess patients at least once daily (physical examination, haemodynamic status, stool } \\
\text { charts, blood tests } \pm \text { abdominal X-Ray) }\end{array}$ \\
$\checkmark$ & Correct and prevent dehydration and electrolyte imbalances \\
$\checkmark$ & Avoid NSAIDs, anticholinergic, anti-diarrhoeal, opioid drugs \\
$\checkmark$ & Assess and optimise nutritional status-encourage enteral nutrition \\
$\checkmark$ & Initiate prophylaxis for VTE \\
$\checkmark$ & Avoid routine use of antibiotics \\
$\checkmark$ & Consider topical therapy if tolerated \\
$\checkmark$ & Maintain a haemoglobin above 8-10 g/dL, prefer intravenous iron supplementation \\
\hline
\end{tabular}


therapy [37-39]. For this reason, antibiotics are only recommended when infection is considered (for example, in a first attack of short duration, after recent admission in hospital or after travel to an area where amoebiasis is endemic) or immediately prior to surgery $[9,40]$.

There is no definite evidence for continuation of 5-aminosalicylic acid (5-ASA) therapy [26]. However, current guidelines recommend topical therapy (either 5-ASA or corticosteroids) if this can be tolerated by the patient and retained [9].

Blood transfusion is indicated if required to maintain a haemoglobin above $8-10 \mathrm{~g} / \mathrm{dl}[9,41]$. If iron supplementation is needed, then intravenous iron should be preferred and is recommended by current ECCO guidelines as it is more effective, shows a faster response and is better tolerated than oral iron [41].

\section{Treatment}

\section{Corticosteroids}

Ever since the pivotal article of Truelove and Witts, intravenous corticosteroids have been the cornerstone in the management of acute severe ulcerative colitis [8]. Use of intravenous corticosteroids in the management of ASUC has led to a decrease in the morbidity and mortality associated with a severe flare of UC [7, 42]. Current guidelines recommend using methylprednisolone $60 \mathrm{mg}$ every $24 \mathrm{~h}$ or hydrocortisone $100 \mathrm{mg}$ four times daily $[9,10,12,40]$. There is no proven effectiveness from higher doses, but lower doses are less effective, and a bolus injection is as effective as continuous infusion [7, 43, 44]. A systematic review including 1991 patients from 32 trials of steroid therapy for ASUC between the years 1974 and 2006, reported on overall response to steroids (including intravenous hydrocortisone, methylprednisolone and betamethasone) of $67 \%$ and this outcome did not change between 1974 and 2006 [7]. Treatment with steroids should be given for a defined period and extending therapy beyond 7-10 days carries an increased risk of toxicity without adding any benefit $[7,45]$. According to the current guidelines, patients should be assessed after three days of intravenous corticosteroid therapy and those not responding should be considered for salvage medical or surgical therapy $[10,40]$.

\section{Predictors of outcomes in ASUC, response to corticosteroid therapy and indicators for rescue therapy}

Several markers have been studied as predictors of outcome in ASUC. These can be divided into clinical, biochemical, endoscopic and radiological and several indices and scoring systems have been developed, that can potentially predict disease outcomes and therefore guide patient management. Low albumin levels have been associated with an increased risk for colectomy $[46,47]$ and a CRP/albumin ratio of 0.85 on day 3 of intravenous steroid therapy was found to predict the need for colectomy with a sensitivity of $70 \%$ and specificity of $76 \%$ in one study [48]. Endoscopic markers can also be used as predictors and severe endoscopic lesions including deep ulcers, extensive loss of mucosal layers, welllike ulcers or large erosions have been associated with nonresponse to corticosteroids [49] and need for colectomy [50]. As previously mentioned, a UCEIS of $\geq 7$ on admission is a predictor of the need of rescue therapy or colectomy [25]. The use of faecal calprotectin as a predictor of failure of corticosteroid therapy has also been investigated. A prospective cohort study by Jain et al. found that all patients with UCEIS $>6$ on admission and faecal calprotectin $>1000 \mu \mathrm{g} / \mathrm{g}$ on day 3 failed steroid therapy [51].

Up to one-third of patients will fail to respond to intravenous corticosteroids and it is therefore very important that patients are assessed in a timely manner to identify those that need to be considered for salvage therapy either medical or surgical. The most commonly used criteria which are endorsed in current guidelines are the Oxford criteria [10, 52]. These are defined by $>8$ stools per day or three to eight stools per day with a CRP $>45 \mathrm{mg} / \mathrm{L}$ on day 3 of intravenous steroid therapy and correspond to $85 \%$ rate of colectomy [52]. The Oxford criteria are the simplest to apply in clinical practice. The Edinburg risk score described by Ho et al., assesses the mean stool frequency over the first three days of admission, along with the presence of colonic dilatation $(>5.5 \mathrm{~cm})$ and hypoalbuminaemia $(<30 \mathrm{~g} / \mathrm{L})$ on the first day of admission. A score of $\geq 4$ can predict failure of corticosteroid therapy with a sensitivity of $85 \%$ and specificity of $75 \%$ [53]. The Swedish index, also known as the fulminant colitis index, is also calculated on day 3 [stool frequency/ day +0.14 X CRP $\mathrm{mg} / \mathrm{L}]$ and a score of $\geq 8$ has a positive predictive value of $72 \%$ for colectomy [54]. (Table 4).

According to current guidelines, all patients with ASUC that are assessed by a suitable scoring system and fail to respond to intravenous corticosteroid therapy by day 3 should be offered rescue therapy $[9,10]$.

\section{Rescue therapies in ASUC}

\section{Calcineurin inhibitors}

Cyclosporine given intravenously was the first agent to be used with proven efficacy as second-line treatment in patients with steroid-refractory severe UC. The first trial on cyclosporine in ASUC by Lichtiger et al. in 1994, demonstrated efficacy of intravenous dose of $4 \mathrm{mg} / \mathrm{kg} /$ day [55]. 
Table 4 Predictors of failure of corticosteroid therapy or colectomy

To be assessed at day 3 of intravenous corticosteroids

Travis et al. [52]

Ho et al. [53]

Lindgren et al. [54]

Gibson et al. [48]

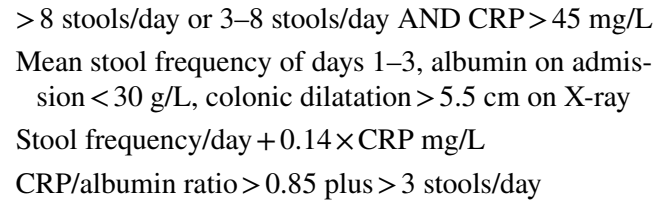

$85 \%$ chance of colectomy

$85 \%$ chance of treatment failure if score $\geq 4$

$72 \%$ chance of colectomy if $\geq 8$

$74 \%$ chance of treatment failure
A randomised controlled trial from Belgium showed that cyclosporine given intravenously at $2 \mathrm{mg} / \mathrm{kg} / \mathrm{day}$ had similar efficacy to the higher dose of $4 \mathrm{mg} / \mathrm{kg} /$ day used initially [56]. Current guidelines recommend cyclosporine $2 \mathrm{mg} / \mathrm{kg} /$ day as salvage therapy with a target trough cyclosporine concentration of 150-250 ng/mL. Response to cyclosporine should be assessed between days 4-7 and patients who responded should be switched to an oral dose twice the intravenous dose. This is administered in divided doses twice daily with a target trough level of 100-200 ng/mL [10]. Oral cyclosporine should be continued for several months and used as a bridging therapy for the introduction of a thiopurine, either Azathioprine or Mercaptopurine, which will then be used as maintenance therapy after tapering of cyclosporine [10]. Patients who had been treated with thiopurines as maintenance therapy prior to the episode of ASUC and had inadequate response, should not receive cyclosporine as rescue therapy and alternatives should be considered [12].

Cyclosporine use in ASUC has been limited by the relative common side effects associated with its use. Treatment with cyclosporine has been associated with serious infections $(6.3 \%)$, anaphylaxis $(0.9 \%)$, nephrotoxicity $(5.4 \%)$ and neurotoxicity (seizures $3.6 \%$ ), as well as a mortality of $1.8 \%$ [57]. Cyclosporine should be avoided in patients with hypocholesterolaemia (cholesterol level $<1.15 \mathrm{mg} / \mathrm{L}$ ) and hypomagnesaemia (serum magnesium $<1.4 \mathrm{mg} / \mathrm{L}$ ) because some of the neurotoxicity seen with the use of cyclosporine has been associated with these two conditions [57]. Nephrotoxicity as indicated by a rise in serum creatinine is typically mild and may respond to lowering of the dose of cyclosporine [57]. Magnesium, cholesterol and creatinine should be measured at baseline and after $48 \mathrm{~h}$ of treatment with cyclosporine [58]. Patients who respond to cyclosporine and start maintenance therapy with thiopurines, should also receive prophylactic antibiotic therapy for Pneumocystis jirovecii (trimethoprim-sulfamethoxazole 160/800 mg three times a week) while on triple immunosuppression with oral steroids more than an equivalent to $20 \mathrm{mg}$ of prednisolone [22].

Tacrolimus is an alternative calcineurin inhibitor which can be administered orally and has a similar mechanism of action to cyclosporine. There have been only a few studies on the use of tacrolimus in ASUC; however, a systematic review and meta-analysis by Komaki et al. demonstrated the efficacy of tacrolimus, showing that clinical response at two weeks of therapy was higher with tacrolimus compared to placebo $\left(\mathrm{RR}=4.61,95 \% \mathrm{CI} 2.09-10.17, p=0.15 \times 10^{-3}\right.$ ) and colectomy-free rates reached $69 \%$ at 12 months [59]. Tacrolimus has a similar safety profile to cyclosporine with various side effects including infections, tremor and nephrotoxicity [59]. Current ECCO guidelines recognise tacrolimus as a possible alternative rescue therapy for ASUC [9], even though it is not widely used in clinical practice.

\section{Infliximab}

Infliximab is a chimeric $\operatorname{IgG} 1$ monoclonal antibody specifically targeted against free and membrane-bound TNF- $\alpha$ which has proven efficacy in ASUC [60] and has become the most commonly used salvage therapy. In a randomised controlled trial by Järnerot et al., patients who were initially treated with IV betamethasone and received a single dose infliximab $(5 \mathrm{mg} / \mathrm{kg})$ as salvage therapy, had a significantly lower 3-month colectomy rate compared to placebo [61]. Long-term follow-up data showed that the benefit of rescue therapy with infliximab in ASUC remained after 3 years [62].

The standard induction regime for infliximab is $5 \mathrm{mg} / \mathrm{kg}$ at weeks 0,2 and 6 [12] and for patients who have responded to infliximab, combination therapy with a thiopurine should always be considered, even in those who had previously failed thiopurine monotherapy [10]. There is evidence that combination therapy can result to increased blood levels of infliximab and decreased immunogenicity against infliximab [63].

Infliximab is contraindicated in congestive cardiac failure (New York Heart Association Class III/IV), demyelinating disease, active sepsis and latent tuberculosis and screening tests as described earlier should be performed prior to commencement of treatment [10]. Prophylactic therapy for Pneumocystis jirovecii should once again be considered for patients on triple immunosuppression. Infliximab may also have an impact on peri-operative complications and this needs to be taken into consideration, although data are mixed. Some studies did not show any significant increase in postoperative complications in patients with $\mathrm{UC}$ who had 
received infliximab pre-operatively [64], whereas others reported a worse postoperative morbidity since the introduction of biologics in therapy [65].

\section{Comparing infliximab and cyclosporine}

Two head-to-head studies have compared efficacy of infliximab and cyclosporine for ASUC showing equivalence among the two medications. In the open-label CYSIF trial, there was no statistically significant difference between infliximab and cyclosporine in treatment failure, adverse events, mucosal healing rates, colectomy rates and colectomy-free survival at 1 and 5 years [66]. The CONSTRUCT trial was an open-label pragmatic randomised trial of infliximab and cyclosporine and again showed no significant difference in clinical effectiveness [67]. Moreover, a systematic review and meta-analysis of infliximab and cyclosporine randomised controlled trials showed no difference in response rates up to 1 year of therapy [68]. Cyclosporine and infliximab are equally effective in ASUC, but infliximab is simpler in use although more expensive [10]. The choice between rescue therapies should be individualised and several other factors, such as co-morbidities, contra-indications, previous exposure to medications, expertise and feasibility of laboratory testing, should be taken into consideration on decision [27].

\section{Sequential therapy in ASUC}

Sequential therapy is defined as the use of a calcineurin inhibitor as rescue therapy in patients not responding to infliximab and vice versa. Sequential therapy is not recommended by current guidelines as it has been associated with serious side effects and infections because of cumulative immunosuppression $[10,40]$. According to ECCO guidelines, only one attempt at rescue therapy should be considered before referral for colectomy and third-line medical therapy should only be considered in specialist referral centres and highly selected cases [9].

\section{Accelerated/intensified Infliximab dosing for ASUC}

Two studies have demonstrated that higher infliximab serum concentrations are associated with greater efficacy and better outcomes $[69,70]$. Moreover, the are several other factors that would support the need for dose optimisation of infliximab in the acute phase. These include the high TNF burden in ASUC, the proteolytic degradation of anti-TNF associated with increased drug clearance and faecal losses from increased gut permeability associated with severe inflammation [71]. According to BSG guidelines, patients who have not responded sufficiently 3-5 days after the first infliximab infusion should be treated with an accelerated induction regimen after a colorectal surgical review to exclude the need for emergency colectomy [10]. Some clinicians also use an initial $10 \mathrm{mg} / \mathrm{kg}$ dose as salvage therapy, however, optimal timing and dose are yet to be defined and further studies are needed for dose intensification to be implemented into clinical practice.

\section{Surgery for ASUC}

The efficacy of rescue therapy in ASUC should be assessed daily [12] and although there have been no studies evaluating when rescue therapy should be considered unsuccessful, current guidelines recommend that patients with ASUC who have not responded within 7 days of rescue therapy require surgery [10, 12]. Colectomy should also be considered for patients who deteriorate prior to that time, or in case of complications, such as toxic megacolon, severe haemorrhage or perforation $[10,12]$. Studies have shown that delayed surgery is associated with increased risk of complications [45] and that the only significant predictor of postoperative complications is a prolonged admission prior to surgery [72]. For this reason, it is imperative that decisions are made in a timely manner, in a multidisciplinary team setting, involving gastroenterologist, colorectal surgeon and stoma therapist if possible. Careful counselling is required so that surgical procedure, outcomes and possible complications are explained to the patient [12]. Colectomy should be considered as a treatment option and not an outcome that needs to be avoided at any cost [10]. The procedure of choice for patients with ASUC is total or subtotal colectomy with end ileostomy and preservation of rectum. The rectal stump may be managed by intraperitoneal closure or can be brought forward as a mucus fistula. The procedure can be performed open or laparoscopically based on local expertise. Subtotal colectomy is a safe procedure even in the setting of ASUC, it allows the patient to be relieved from disease burden, stabilize and recover. Moreover, it avoids pelvic dissection and intestinal anastomosis therefore minimising the potential for anastomotic leak. Definite histological confirmation can be obtained if needed and corticosteroids and immunosuppressant therapy can be weaned off prior to any further surgery. Restorative proctocolectomy with ileal pouch anal anastomosis (IPAA) is usually performed as a more definite procedure at a later stage $[12,26,40]$.

\section{Emerging therapies}

Two other anti-TNF agents, adalimumab and golimumab, and vedolizumab-a monoclonal antibody targeting the $\alpha_{4} \beta_{7}$ integrin-have demonstrated efficacy in the treatment of moderate-to-severe UC [73-75]; however, there have been no specific studies for ASUC patients. Two recent studies have shown that vedolizumab can be effectively 
used as maintenance therapy in patients responding to calcineurin inhibitors [76, 77] and although further data are required, this can be kept into consideration in patients who had previously failed thiopurines and require cyclosporine as rescue therapy for ASUC. Tofacitinib is an oral Janus kinase (JAK) inhibitor which has proven effective in the treatment of moderate-to-severe UC. A recent post hoc analysis indicated a rapid onset of action with significant improvement on symptoms by day 3 of induction therapy with tofacitinib in UC [78]. Moreover, highintensity tofacitinib was used successfully in 4 patients with ASUC [79]. Clearly, further randomised studies are required however, these data suggest that tofacitinib could potentially be used in the treatment of ASUC in the future. Finally, anakinra-IL-1 antagonist used for the treatment of patients with rheumatoid arthritis-is currently investigated as potential co-treatment with corticosteroids for ASUC [80].

\section{Conclusion}

Acute severe ulcerative colitis is a medical emergency that warrants in-patient management. This is best served within a multidisciplinary team setting in specialised centres or with expert consultation. Intravenous corticosteroids remain the cornerstone in the management of ASUC and should be initiated promptly, along with general management measures and close monitoring of patients. Unfortunately, one-third of patients will fail to respond to steroids. Response to intravenous corticosteroid therapy needs to be assessed on the third day and rescue therapies, including cyclosporine and infliximab, should be offered to patients not responding. Choice of rescue therapy depends on experience, drug availability and factors associated with each individual patient, such as comorbidities, previous medications or contra-indications to therapy. Patients who have not responded within 7 days to rescue therapy must be considered for surgery. Surgery is a treatment option in ASUC and should not be delayed in cases of failure of medical therapy, because such delays increase surgical morbidity and mortality. Further research might help in defining predictors of response to salvage therapy and optimal dosing regimens, thus leading to a more personalised treatment for patients. Finally, further studies are required to investigate the potential benefit of other agents in the management of ASUC.

Author contributions CPS conceived the article. KR wrote the draft manuscript and CPS critically reviewed the manuscript.

Funding No funding was received for this article.

\section{Declarations}

Conflict of interest KR had speaker arrangements with Takeda. CPS has received unrestricted research grants from Warner Chilcott, Janssen and AbbVie, has provided consultancy to Warner Chilcott, Dr. Falk, AbbVie, Takeda, Fresenius Kabi and Janssen, and had speaker arrangements with Warner Chilcott, Dr. Falk, AbbVie, MSD, Pfizer and Takeda.

Open Access This article is licensed under a Creative Commons Attribution 4.0 International License, which permits use, sharing, adaptation, distribution and reproduction in any medium or format, as long as you give appropriate credit to the original author(s) and the source, provide a link to the Creative Commons licence, and indicate if changes were made. The images or other third party material in this article are included in the article's Creative Commons licence, unless indicated otherwise in a credit line to the material. If material is not included in the article's Creative Commons licence and your intended use is not permitted by statutory regulation or exceeds the permitted use, you will need to obtain permission directly from the copyright holder. To view a copy of this licence, visit http://creativecommons.org/licenses/by/4.0/.

\section{References}

1. Magro F, Gionchetti P, Eliakim R, Ardizzone S, Armuzzi A, Barreiro-de Acosta M, Burisch J, Gecse KB, Hart AL, Hindryckx P, Langner C, Limdi JK, Pellino G, Zagórowicz E, Raine T, Harbord M, Rieder F, European Crohn's and Colitis Organisation [ECCO] (2017) Third European evidence-based consensus on diagnosis and management of ulcerative colitis. Part 1: definitions, diagnosis, extra-intestinal manifestations, pregnancy, cancer surveillance, surgery, and ileo-anal pouch disorders. J Crohns Colitis 11(6):649-670. https://doi.org/10.1093/ecco-jcc/jjx008

2. Molodecky NA, Soon IS, Rabi DM, Ghali WA, Ferris M, Chernoff G, Benchimol EI, Panaccione R, Ghosh S, Barkema HW, Kaplan GG (2012) Increasing incidence and prevalence of the inflammatory bowel diseases with time, based on systematic review. Gastroenterology 142(1):46-54.e42. https://doi.org/10.1053/j.gastro. 2011.10.001 (quiz e30)

3. Ungaro R, Mehandru S, Allen PB, Peyrin-Biroulet L, Colombel JF (2017) Ulcerative colitis. Lancet 389(10080):1756-1770. https:// doi.org/10.1016/S0140-6736(16)32126-2

4. Dinesen LC, Walsh AJ, Protic MN, Heap G, Cummings F, Warren BF, George B, Mortensen NJ, Travis SP (2010) The pattern and outcome of acute severe colitis. J Crohns Colitis 4(4):431-437. https://doi.org/10.1016/j.crohns.2010.02.001

5. Edwards FC, Truelove SC (1963) The course and prognosis of ulcerative colitis. Gut 4(4):299-315. https://doi.org/10.1136/gut.4. 4.299

6. Lynch RW, Lowe D, Protheroe A, Driscoll R, Rhodes JM, Arnott ID (2013) Outcomes of rescue therapy in acute severe ulcerative colitis: data from the United Kingdom inflammatory bowel disease audit. Aliment Pharmacol Ther 38(8):935-945. https://doi. org/10.1111/apt.12473

7. Turner D, Walsh CM, Steinhart AH, Griffiths AM (2007) Response to corticosteroids in severe ulcerative colitis: a systematic review of the literature and a meta-regression. Clin Gastroenterol Hepatol 5(1):103-110. https://doi.org/10.1016/j.cgh.2006. 09.033

8. Truelove SC, Witts LJ (1955) Cortisone in ulcerative colitis; final report on a therapeutic trial. Br Med J 2(4947):1041-1048. https:// doi.org/10.1136/bmj.2.4947.1041 
9. Harbord M, Eliakim R, Bettenworth D, Karmiris K, Katsanos K, Kopylov U, Kucharzik T, Molnár T, Raine T, Sebastian S, de Sousa HT, Dignass A, Carbonnel F; European Crohn's and Colitis Organisation [ECCO] (2017) Third European evidence-based consensus on diagnosis and management of ulcerative colitis. Part 2: current management. J Crohns Colitis 11(7):769-784. https:// doi.org/10.1093/ecco-jcc/jjx009 (Erratum in: J Crohns Colitis. 2017 Dec 4;11(12):1512).

10. Lamb CA, Kennedy NA, Raine T, Hendy PA, Smith PJ, Limdi JK, Hayee B, Lomer MCE, Parkes GC, Selinger C, Barrett KJ, Davies RJ, Bennett C, Gittens S, Dunlop MG, Faiz O, Fraser A, Garrick V, Johnston PD, Parkes M, Sanderson J, Terry H, IBD guidelines eDelphi Consensus Group, Gaya DR, Iqbal TH, Taylor SA, Smith M, Brookes M, Hansen R, Hawthorne AB (2019) British Society of Gastroenterology consensus guidelines on the management of inflammatory bowel disease in adults. Gut 68(Suppl 3):s1-s106. https://doi.org/10.1136/gutjnl-2019-318484

11. Osei-Bimpong A, Meek JH, Lewis SM (2007) ESR or CRP? A comparison of their clinical utility. Hematology 12(4):353-357. https://doi.org/10.1080/10245330701340734

12. Chen JH, Andrews JM, Kariyawasam V, Moran N, Gounder P, Collins G, Walsh AJ, Connor S, Lee TW, Koh CE, Chang J, Paramsothy S, Tattersall S, Lemberg DA, Radford-Smith G, Lawrance IC, McLachlan A, Moore GT, Corte C, Katelaris P, Leong RW, IBD Sydney Organisation and the Australian Inflammatory Bowel Diseases Consensus Working Group (2016) Review article: acute severe ulcerative colitis-evidence-based consensus statements. Aliment Pharmacol Ther 44(2):127-144. https://doi.org/ 10.1111/apt.13670

13. Trifan A, Stanciu C, Stoica O, Girleanu I, Cojocariu C (2014) Impact of Clostridiumdifficile infection on inflammatory bowel disease outcome: a review. World J Gastroenterol 20(33):1173611742. https://doi.org/10.3748/wjg.v20.i33.11736

14. Rodemann JF, Dubberke ER, Reske KA, Seo DH, Stone CD (2007) Incidence of Clostridiumdifficile infection in inflammatory bowel disease. Clin Gastroenterol Hepatol 5(3):339-344. https:// doi.org/10.1016/j.cgh.2006.12.027

15. Jen MH, Saxena S, Bottle A, Aylin P, Pollok RC (2011) Increased health burden associated with Clostridiumdifficile diarrhoea in patients with inflammatory bowel disease. Aliment Pharmacol Ther 33(12):1322-1331. https://doi.org/10.1111/j.1365-2036. 2011.04661.x

16. Deshpande A, Pasupuleti V, Patel P, Pant C, Pagadala M, Hall G, Hu B, Jain A, Rolston DD, Sferra TJ, Atreja A (2012) Repeat stool testing for Clostridiumdifficile using enzyme immunoassay in patients with inflammatory bowel disease increases diagnostic yield. Curr Med Res Opin 28(9):1553-1560. https://doi.org/10. 1185/03007995.2012.717529

17. Aichinger E, Schleck CD, Harmsen WS, Nyre LM, Patel R (2008) Nonutility of repeat laboratory testing for detection of Clostridiumdifficile by use of PCR or enzyme immunoassay. J Clin Microbiol 46(11):3795-3797. https://doi.org/10.1128/JCM.00684-08

18. Chew CN, Nolan DJ, Jewell DP (1991) Small bowel gas in severe ulcerative colitis. Gut 32(12):1535-1537. https://doi.org/10.1136/ gut.32.12.1535

19. da Luz MA, Vogel JD, Baker M, Mor I, Zhang R, Fazio V (2009) Does CT influence the decision to perform colectomy in patients with severe ulcerative colitis? J Gastrointest Surg 13(3):504-507. https://doi.org/10.1007/s11605-008-0732-3

20. Maher MM, Nassar MI (2009) Acute cytomegalovirus infection is a risk factor in refractory and complicated inflammatory bowel disease. Dig Dis Sci 54(11):2456-2462. https://doi.org/10.1007/ s10620-008-0639-6

21. Sager K, Alam S, Bond A, Chinnappan L, Probert CS (2015) Review article: cytomegalovirus and inflammatory bowel disease.
Aliment Pharmacol Ther 41(8):725-733. https://doi.org/10.1111/ apt.13124

22. Rahier JF, Magro F, Abreu C, Armuzzi A, Ben-Horin S, Chowers Y, Cottone M, de Ridder L, Doherty G, Ehehalt R, Esteve M, Katsanos K, Lees CW, Macmahon E, Moreels T, Reinisch W, Tilg H, Tremblay L, Veereman-Wauters G, Viget N, Yazdanpanah Y, Eliakim R, Colombel JF, European Crohn's and Colitis Organisation (ECCO) (2014) Second European evidence-based consensus on the prevention, diagnosis and management of opportunistic infections in inflammatory bowel disease. J Crohns Colitis 8(6):443-468. https://doi.org/10.1016/j.crohns.2013.12.013

23. Travis SP, Schnell D, Krzeski P, Abreu MT, Altman DG, Colombel JF, Feagan BG, Hanauer SB, Lémann M, Lichtenstein GR, Marteau PR, Reinisch W, Sands BE, Yacyshyn BR, Bernhardt CA, Mary JY, Sandborn WJ (2012) Developing an instrument to assess the endoscopic severity of ulcerative colitis: The Ulcerative Colitis Endoscopic Index of Severity (UCEIS). Gut 61(4):535-542. https://doi.org/10.1136/gutjnl-2011-300486

24. Travis SP, Schnell D, Krzeski P, Abreu MT, Altman DG, Colombel JF, Feagan BG, Hanauer SB, Lichtenstein GR, Marteau PR, Reinisch W, Sands BE, Yacyshyn BR, Schnell P, Bernhardt CA, Mary JY, Sandborn WJ (2013) Reliability and initial validation of the ulcerative colitis endoscopic index of severity. Gastroenterology 145(5):987-995. https://doi.org/10.1053/j.gastro.2013.07.024

25. Corte C, Fernandopulle N, Catuneanu AM, Burger D, Cesarini M, White L, Keshav S, Travis S (2015) Association between the ulcerative colitis endoscopic index of severity (UCEIS) and outcomes in acute severe ulcerative colitis. J Crohns Colitis 9(5):376381. https://doi.org/10.1093/ecco-jcc/jjv047

26. Jain S, Ahuja V, Limdi JK (2019) Optimal management of acute severe ulcerative colitis. Postgrad Med J 95(1119):32-40. https:// doi.org/10.1136/postgradmedj-2018-136072

27. Sedano R, Quera R, Simian D, Yarur AJ (2019) An approach to acute severe ulcerative colitis. Expert Rev Gastroenterol Hepatol 13(10):943-955. https://doi.org/10.1080/17474124.2019.1681974

28. Felder JB, Korelitz BI, Rajapakse R, Schwarz S, Horatagis AP, Gleim G (2000) Effects of nonsteroidal antiinflammatory drugs on inflammatory bowel disease: a case-control study. Am J Gastroenterol 95(8):1949-1954. https://doi.org/10.1111/j.1572-0241. 2000.02262.x

29. Gan SI, Beck PL (2003) A new look at toxic megacolon: an update and review of incidence, etiology, pathogenesis, and management. Am J Gastroenterol 98(11):2363-2371. https://doi.org/10.1111/j. 1572-0241.2003.07696.x

30. González-Huix F, Fernández-Bañares F, Esteve-Comas M, AbadLacruz A, Cabré E, Acero D, Figa M, Guilera M, Humbert P, de León R et al (1993) Enteral versus parenteral nutrition as adjunct therapy in acute ulcerative colitis. Am J Gastroenterol 88(2):227-232

31. McIntyre PB, Powell-Tuck J, Wood SR, Lennard-Jones JE, Lerebours E, Hecketsweiler P, Galmiche JP, Colin R (1986) Controlled trial of bowel rest in the treatment of severe acute colitis. Gut 27(5):481-485. https://doi.org/10.1136/gut.27.5.481

32. Grainge MJ, West J, Card TR (2010) Venous thromboembolism during active disease and remission in inflammatory bowel disease: a cohort study. Lancet 375(9715):657-663. https://doi.org/ 10.1016/S0140-6736(09)61963-2

33. Kappelman MD, Horvath-Puho E, Sandler RS, Rubin DT, Ullman TA, Pedersen L, Baron JA, Sørensen HT (2011) Thromboembolic risk among Danish children and adults with inflammatory bowel diseases: a population-based nationwide study. Gut 60(7):937943. https://doi.org/10.1136/gut.2010.228585

34. Nguyen GC, Sam J (2008) Rising prevalence of venous thromboembolism and its impact on mortality among hospitalized inflammatory bowel disease patients. Am J Gastroenterol 103(9):22722280. https://doi.org/10.1111/j.1572-0241.2008.02052.x 
35. Saleh T, Matta F, Yaekoub AY, Danescu S, Stein PD (2011) Risk of venous thromboembolism with inflammatory bowel disease. Clin Appl Thromb Hemost 17(3):254-258. https://doi.org/10. $1177 / 1076029609360528$

36. Nguyen GC, Bernstein CN, Bitton A, Chan AK, Griffiths AM, Leontiadis GI, Geerts W, Bressler B, Butzner JD, Carrier M, Chande N, Marshall JK, Williams C, Kearon C (2014) Consensus statements on the risk, prevention, and treatment of venous thromboembolism in inflammatory bowel disease: Canadian Association of Gastroenterology. Gastroenterology 146(3):835-848.e6. https://doi.org/10.1053/j.gastro.2014.01.042

37. Chapman RW, Selby WS, Jewell DP (1986) Controlled trial of intravenous metronidazole as an adjunct to corticosteroids in severe ulcerative colitis. Gut 27(10):1210-1212. https://doi.org/ 10.1136/gut.27.10.1210

38. Mantzaris GJ, Hatzis A, Kontogiannis P, Triadaphyllou G (1994) Intravenous tobramycin and metronidazole as an adjunct to corticosteroids in acute, severe ulcerative colitis. Am J Gastroenterol 89(1):43-46

39. Mantzaris GJ, Petraki K, Archavlis E, Amberiadis P, Kourtessas D, Christidou A, Triantafyllou G (2001) A prospective randomized controlled trial of intravenous ciprofloxacin as an adjunct to corticosteroids in acute, severe ulcerative colitis. Scand J Gastroenterol 36(9):971-974. https://doi.org/10.1080/0036552017 50305503

40. Bitton A, Buie D, Enns R, Feagan BG, Jones JL, Marshall JK, Whittaker S, Griffiths AM, Panaccione R, Canadian Association of Gastroenterology Severe Ulcerative Colitis Consensus Group (2012) Treatment of hospitalized adult patients with severe ulcerative colitis: Toronto consensus statements. Am J Gastroenterol. 107(2):179-194. https://doi.org/10.1038/ajg.2011.386 (author reply 195)

41. Dignass AU, Gasche C, Bettenworth D, Birgegård G, Danese S, Gisbert JP, Gomollon F, Iqbal T, Katsanos K, Koutroubakis I, Magro F, Savoye G, Stein J, Vavricka S, European Crohn's and Colitis Organisation [ECCO] (2015) European consensus on the diagnosis and management of iron deficiency and anaemia in inflammatory bowel diseases. J Crohns Colitis 9(3):211-222. https://doi.org/10.1093/ecco-jcc/jju009

42. Sonnenberg A (2007) Time trends of mortality from Crohn's disease and ulcerative colitis. Int J Epidemiol 36(4):890-899. https:// doi.org/10.1093/ije/dym034

43. Rosenberg W, Ireland A, Jewell DP (1990) High-dose methylprednisolone in the treatment of active ulcerative colitis. J Clin Gastroenterol 12(1):40-41. https://doi.org/10.1097/00004836-19900 2000-00011

44. Bossa F, Fiorella S, Caruso N, Accadia L, Napolitano G, Valvano MR, Andriulli A, Annese V (2007) Continuous infusion versus bolus administration of steroids in severe attacks of ulcerative colitis: a randomized, double-blind trial. Am J Gastroenterol 102(3):601-608. https://doi.org/10.1111/j.1572-0241.2006. 01007.x

45. Randall J, Singh B, Warren BF, Travis SP, Mortensen NJ, George BD (2010) Delayed surgery for acute severe colitis is associated with increased risk of postoperative complications. Br J Surg 97(3):404-409. https://doi.org/10.1002/bjs.6874

46. Kaur M, Berel D, Vasiliauskas EA, Ippoliti A, Dubinsky M, Melmed GY, Shih DQ, Feldman EJ, Fleshner P, Targan S, McGovern DP (2012) Sa1916 Sa1916 A combination of serum albumin and band neutrophil count is predictive of short-term colectomy following infliximab treatment for severe steroid refractory ulcerative colitis. Gastroenterology 142(Suppl 1):S358. https://doi.org/ 10.1016/S0016-5085(12)61351-1

47. Mokhele NN, Thomson SR, Watermeyer GA (2017) Predictors of emergency colectomy in patients admitted with acute severe ulcerative colitis. S Afr J Surg 55(3):20-26
48. Gibson DJ, Hartery K, Doherty J, Nolan J, Keegan D, Byrne K, Martin ST, Buckley M, Sheridan J, Horgan G, Mulcahy HE, Cullen G, Doherty GA (2018) CRP/albumin ratio: an early predictor of steroid responsiveness in acute severe ulcerative colitis. J Clin Gastroenterol 52(6):e48-e52. https://doi.org/10.1097/MCG.00000 00000000884

49. Daperno M, Sostegni R, Scaglione N, Ercole E, Rigazio C, Rocca R, Pera A (2004) Outcome of a conservative approach in severe ulcerative colitis. Dig Liver Dis 36(1):21-28. https://doi.org/10. 1016/j.dld.2003.04.001

50. Monterubbianesi R, Aratari A, Armuzzi A, Daperno M, Biancone L, Cappello M, Annese V, Riegler G, Orlando A, Viscido A, Meucci G, Gasbarrini A, Guidi L, Lavagna A, Sostegni R, Onali S, Papi C, Kohn A, Italian Group for the study of Inflammatory Bowel Disease (IG-IBD) (2014) Infliximab three-dose induction regimen in severe corticosteroid-refractory ulcerative colitis: early and late outcome and predictors of colectomy. J Crohns Colitis 8(8):852-858. https://doi.org/10.1016/j.crohns.2014.01.006

51. Jain S, Kedia S, Bopanna S, Sachdev V, Sahni P, Dash NR, Pal S, Vishnubhatla S, Makharia G, Travis SPL, Ahuja V (2017) Faecal calprotectin and UCEIS predict short-term outcomes in acute severe colitis: prospective cohort study. J Crohns Colitis 11(11):1309-1316. https://doi.org/10.1093/ecco-jcc/jjx084

52. Travis SP, Farrant JM, Ricketts C, Nolan DJ, Mortensen NM, Kettlewell MG, Jewell DP (1996) Predicting outcome in severe ulcerative colitis. Gut 38(6):905-910. https://doi.org/10.1136/gut. 38.6.905

53. Ho GT, Mowat C, Goddard CJ, Fennell JM, Shah NB, Prescott RJ, Satsangi J (2004) Predicting the outcome of severe ulcerative colitis: development of a novel risk score to aid early selection of patients for second-line medical therapy or surgery. Aliment Pharmacol Ther 19(10):1079-1087. https://doi.org/10.1111/j. 1365-2036.2004.01945.x

54. Lindgren SC, Flood LM, Kilander AF, Löfberg R, Persson TB, Sjödahl RI (1998) Early predictors of glucocorticosteroid treatment failure in severe and moderately severe attacks of ulcerative colitis. Eur J Gastroenterol Hepatol 10(10):831-835. https://doi. org/10.1097/00042737-199810000-00003

55. Lichtiger S, Present DH, Kornbluth A, Gelernt I, Bauer J, Galler G, Michelassi F, Hanauer S (1994) Cyclosporine in severe ulcerative colitis refractory to steroid therapy. N Engl J Med 330(26):1841-1845. https://doi.org/10.1056/NEJM19940630330 2601

56. Van Assche G, D'Haens G, Noman M, Vermeire S, Hiele M, Asnong K, Arts J, D’Hoore A, Penninckx F, Rutgeerts P (2003) Randomized, double-blind comparison of $4 \mathrm{mg} / \mathrm{kg}$ versus $2 \mathrm{mg} / \mathrm{kg}$ intravenous cyclosporine in severe ulcerative colitis. Gastroenterology 125(4):1025-1031. https://doi.org/10.1016/s0016-5085(03) 01214-9

57. Sternthal MB, Murphy SJ, George J, Kornbluth A, Lichtiger S, Present DH (2008) Adverse events associated with the use of cyclosporine in patients with inflammatory bowel disease. Am J Gastroenterol 103(4):937-943. https://doi.org/10.1111/j.15720241.2007.01718.x

58. Kedia S, Ahuja V, Tandon R (2014) Management of acute severe ulcerative colitis. World J Gastrointest Pathophysiol 5(4):579588. https://doi.org/10.4291/wjgp.v5.i4.579

59. Komaki Y, Komaki F, Ido A, Sakuraba A (2016) Efficacy and safety of tacrolimus therapy for active ulcerative colitis; a systematic review and meta-analysis. J Crohns Colitis 10(4):484-494. https://doi.org/10.1093/ecco-jcc/jjv221

60. Lees CW, Heys D, Ho GT, Noble CL, Shand AG, Mowat C, Boulton-Jones R, Williams A, Church N, Satsangi J, Arnott ID, Scottish Society of Gastroenterology Infliximab Group (2007) A retrospective analysis of the efficacy and safety of infliximab as 
rescue therapy in acute severe ulcerative colitis. Aliment Pharmacol Ther 26(3):411-419. https://doi.org/10.1111/j.1365-2036. 2007.03383.x

61. Järnerot G, Hertervig E, Friis-Liby I, Blomquist L, Karlén P, Grännö C, Vilien M, Ström M, Danielsson A, Verbaan H, Hellström PM, Magnuson A, Curman B (2005) Infliximab as rescue therapy in severe to moderately severe ulcerative colitis: a randomized, placebo-controlled study. Gastroenterology 128(7):18051811. https://doi.org/10.1053/j.gastro.2005.03.003

62. Gustavsson A, Järnerot G, Hertervig E, Friis-Liby I, Blomquist L, Karlén P, Grännö C, Vilien M, Ström M, Verbaan H, Hellström PM, Magnuson A, Halfvarson J, Tysk C (2010) Clinical trial: colectomy after rescue therapy in ulcerative colitis-3-year follow-up of the Swedish-Danish controlled infliximab study. Aliment Pharmacol Ther 32(8):984-989. https://doi.org/10.1111/j. 1365-2036.2010.04435.x

63. Hayes MJ, Stein AC, Sakuraba A (2014) Comparison of efficacy, pharmacokinetics, and immunogenicity between infliximab monoversus combination therapy in ulcerative colitis. J Gastroenterol Hepatol 29(6):1177-1185. https://doi.org/10.1111/jgh.12517

64. Billioud V, Ford AC, Tedesco ED, Colombel JF, Roblin X, Peyrin-Biroulet L (2013) Preoperative use of anti-TNF therapy and postoperative complications in inflammatory bowel diseases: a meta-analysis. J Crohns Colitis 7(11):853-867. https://doi.org/10. 1016/j.crohns.2013.01.014

65. Abelson JS, Michelassi F, Mao J, Sedrakyan A, Yeo H (2018) Higher surgical morbidity for ulcerative colitis patients in the era of biologics. Ann Surg 268(2):311-317. https://doi.org/10.1097/ SLA.0000000000002275

66. Laharie D, Bourreille A, Branche J, Allez M, Bouhnik Y, Filippi J, Zerbib F, Savoye G, Vuitton L, Moreau J, Amiot A, Cosnes J, Ricart E, Dewit O, Lopez-Sanroman A, Fumery M, Carbonnel F, Bommelaer G, Coffin B, Roblin X, van Assche G, Esteve M, Farkkila M, Gisbert JP, Marteau P, Nahon S, de Vos M, Lambert J, Mary JY, Louis E, Groupe d'Etudes Thérapeutiques des Affections Inflammatoires Digestives (2018) Long-term outcome of patients with steroid-refractory acute severe UC treated with ciclosporin or infliximab. Gut 67(2):237-243. https://doi.org/10. 1136/gutjnl-2016-313060

67. Williams JG, Alam MF, Alrubaiy L, Arnott I, Clement C, Cohen D, Gordon JN, Hawthorne AB, Hilton M, Hutchings HA, Jawhari AU, Longo M, Mansfield J, Morgan JM, Rapport F, Seagrove AC, Sebastian S, Shaw I, Travis SP, Watkins A (2016) Infliximab versus ciclosporin for steroid-resistant acute severe ulcerative colitis (CONSTRUCT): a mixed methods, open-label, pragmatic randomised trial. Lancet Gastroenterol Hepatol 1(1):15-24. https:// doi.org/10.1016/S2468-1253(16)30003-6

68. Narula N, Marshall JK, Colombel JF, Leontiadis GI, Williams JG, Muqtadir Z, Reinisch W (2016) Systematic review and metaanalysis: infliximab or cyclosporine as rescue therapy in patients with severe ulcerative colitis refractory to steroids. Am J Gastroenterol 111(4):477-491. https://doi.org/10.1038/ajg.2016.7

69. Seow CH, Newman A, Irwin SP, Steinhart AH, Silverberg MS, Greenberg GR (2010) Trough serum infliximab: a predictive factor of clinical outcome for infliximab treatment in acute ulcerative colitis. Gut 59(1):49-54. https://doi.org/10.1136/gut.2009.183095

70. Adedokun OJ, Sandborn WJ, Feagan BG, Rutgeerts P, Xu Z, Marano CW, Johanns J, Zhou H, Davis HM, Cornillie F, Reinisch W (2014) Association between serum concentration of infliximab and efficacy in adult patients with ulcerative colitis. Gastroenterology 147(6):1296-1307.e5. https://doi.org/10.1053/j.gastro.2014. 08.035

71. Hindryckx P, Novak G, Vande Casteele N, Laukens D, Parker C, Shackelton LM, Narula N, Khanna R, Dulai P, Levesque BG, Sandborn WJ, D'Haens G, Feagan BG, Jairath V (2017) Review article: dose optimisation of infliximab for acute severe ulcerative colitis. Aliment Pharmacol Ther 45(5):617-630. https://doi.org/ 10.1111/apt.13913

72. Coakley BA, Telem D, Nguyen S, Dallas K, Divino CM (2013) Prolonged preoperative hospitalization correlates with worse outcomes after colectomy for acute fulminant ulcerative colitis. Surgery 153(2):242-248. https://doi.org/10.1016/j.surg.2012.08. 002

73. Reinisch W, Sandborn WJ, Hommes DW, D'Haens G, Hanauer S, Schreiber S, Panaccione R, Fedorak RN, Tighe MB, Huang B, Kampman W, Lazar A, Thakkar R (2011) Adalimumab for induction of clinical remission in moderately to severely active ulcerative colitis: results of a randomised controlled trial. Gut 60(6):780-787. https://doi.org/10.1136/gut.2010.221127

74. Sandborn WJ, Feagan BG, Marano C, Zhang H, Strauss R, Johanns J, Adedokun OJ, Guzzo C, Colombel JF, Reinisch W, Gibson PR, Collins J, Järnerot G, Hibi T, Rutgeerts P, PURSUITSC Study Group (2014) Subcutaneous golimumab induces clinical response and remission in patients with moderate-to-severe ulcerative colitis. Gastroenterology 146(1):85-95. https://doi.org/ 10.1053/j.gastro.2013.05.048 (quiz e14-5)

75. Feagan BG, Rutgeerts P, Sands BE, Hanauer S, Colombel JF, Sandborn WJ, Van Assche G, Axler J, Kim HJ, Danese S, Fox I, Milch C, Sankoh S, Wyant T, Xu J, Parikh A, GEMINI 1 Study Group (2013) Vedolizumab as induction and maintenance therapy for ulcerative colitis. N Engl J Med 369(8):699-710. https://doi. org/10.1056/NEJMoa1215734

76. Christensen B, Gibson PR, Micic D, Colman RJ, Goeppinger SR, Kassim O, Yarur A, Weber CR, Cohen RD, Rubin DT (2019) Safety and efficacy of combination treatment with calcineurin inhibitors and vedolizumab in patients with refractory inflammatory bowel disease. Clin Gastroenterol Hepatol 17(3):486-493. https://doi.org/10.1016/j.cgh.2018.04.060

77. Pellet G, Stefanescu C, Carbonnel F, Peyrin-Biroulet L, Roblin X, Allimant C, Nachury M, Nancey S, Filippi J, Altwegg R, Brixi H, Fotsing G, de Rosamel L, Shili S, Laharie D, Groupe d'Etude Thérapeutique des Affections Inflammatoires du tube Digestif (2019) Efficacy and safety of induction therapy with calcineurin inhibitors in combination with vedolizumab in patients with refractory ulcerative colitis. Clin Gastroenterol Hepatol 17(3):494-501. https://doi.org/10.1016/j.cgh.2018.08.081

78. Hanauer S, Panaccione R, Danese S, Cheifetz A, Reinisch W, Higgins PDR, Woodworth DA, Zhang H, Friedman GS, Lawendy N, Quirk D, Nduaka CI, Su C (2019) Tofacitinib induction therapy reduces symptoms within 3 days for patients with ulcerative colitis. Clin Gastroenterol Hepatol 17(1):139-147. https://doi.org/10. 1016/j.cgh.2018.07.009

79. Berinstein JA, Steiner CA, Regal RE, Allen JI, Kinnucan JAR, Stidham RW, Waljee AK, Bishu S, Aldrich LB, Higgins PDR (2019) Efficacy of induction therapy with high-intensity tofacitinib in 4 patients with acute severe ulcerative colitis. Clin Gastroenterol Hepatol. 17(5):988-990.e1. https://doi.org/10.1016/j. cgh.2018.11.022

80. Thomas MG, Bayliss C, Bond S, Dowling F, Galea J, Jairath V, Lamb C, Probert C, Timperley-Preece E, Watson A, Whitehead L, Williams JG, Parkes M, Kaser A, Raine T (2019) Trial summary and protocol for a phase II randomised placebo-controlled double-blinded trial of Interleukin 1 blockade in Acute Severe Colitis: the IASO trial. BMJ Open 9(2):e023765. https://doi.org/ 10.1136/bmjopen-2018-023765

Publisher's Note Springer Nature remains neutral with regard to jurisdictional claims in published maps and institutional affiliations. 